\title{
First record of Pediacus dermestoides (Fabricius, 1792) (Coleoptera: Cucujidae) for Bulgaria
}

\author{
Denis Gradinarov¹, Ognyan Sivilov², Danail Doychev ${ }^{3}$
}

(1) Faculty of Biology, Sofia University “St Kliment Ohridski”, 8 Dragan Tzankov Blvd, 1164 Sofia, Bulgaria, dgradinarov@abv.bg; https://orcid.org/0000-0002-6128-5009

(2) Faculty of Biology, Sofia University “St Kliment Ohridski”, 8 Dragan Tzankov Blvd, 1164 Sofia, Bulgaria, osivilov@gmail.com; https://orcid.org/0000-0003-3497-8237

(3) University of Forestry, 10 St Kliment Ohridski Blvd, 1797 Sofia, Bulgaria, doychev@abv.bg; https://orcid.org/0000-0003-1109-6194

\begin{abstract}
The saproxylic species Pediacus dermestoides (Fabricius, 1792) is reported from forest habitats located in five mountains in Bulgaria. The adult beetles were found under the bark of several host tree species or captured with flight interception traps. It seems that $P$. dermestoides might be widespread in the mountain forests in Bulgaria.
\end{abstract}

Keywords: Balkan Peninsula, distribution, forest habitats, saproxylic species

Two genera of the family Cucujidae occur in the Palaearctic: Cucujus Fabricius, 1775 and Pediacus Shuckard, 1839 (Wegrzynowicz, 2007). In Europe, $C$. cinnaberinus Scopoli, 1763 is a threatened species (Cálix et al., 2018). Recently the species was firstly reported or confirmed for a number of Balkan countries, including Bulgaria (e.g. Guéorguiev et al., 2008; Kulijer \& Miljević, 2017; Gjorgjievska et al., 2020). The species of the genus Pediacus are less intensively studied by researchers and no records have been available for Bulgaria until now. In the present work the species P. dermestoides (Fabricius, 1792) is reported for the first time for the country.

\section{Methods}

The material for the present study was collected sporadically in the period of 2005-2020 from five mountain regions in Bulgaria: Maleshevska Planina Mts, Osogovska Planina Mts, Lyulin Mts, Western Rhodopes Mts and Stara Planina Mts (Central Balkan
Range). The specimens were obtained by direct examination of suitable microhabitats (under the bark of dead trees), from collected wood samples or using flight interception traps. The abbreviations used in the material description are as follows: ex. - specimen/s; [BFUS] - Zoological Collection of Sofia University "St Kliment Ohridski", Faculty of Biology, Sofia, Bulgaria; [UF] - Entomological collection of University of Forestry, Sofia, Bulgaria.

\section{Results and discussion}

Pediacus dermestoides (Fabricius, 1792) (Fig. 1A, B)

Material: Maleshevska Planina Mts, $1.5 \mathrm{~km}$ NE of

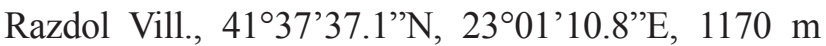
a.s.1., 30.v. - 07.vii.2005, 1 ex., from fallen trunk of Pinus sylvestris L., with two adults of Ips acuminatus (Gyllenhal, 1827), found dead, D. Doychev leg. [UF]; Osogovska Planina Mts, $6.5 \mathrm{~km} \mathrm{~S}$ of Novo Selo Vill., $42^{\circ} 08^{\prime} 11.9^{\prime \prime} \mathrm{N}, \quad 22^{\circ} 40^{\prime} 31.7^{\prime} \mathrm{E}, \quad 1270 \mathrm{~m}$ a.s.1., 


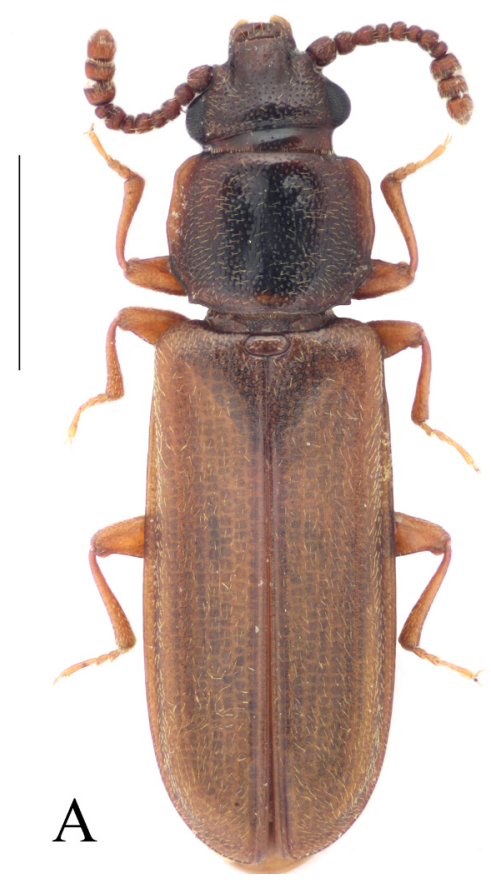

$\leftarrow$ Fig. 1. Pediacus dermestoides, male, Peshtera locality: (A) dorsal view, (B) aedeagus. Scale bars: $1 \mathrm{~mm}$.

08.ix.2016, 1 ex., fallen trunk of Pseudotsuga menziesii (Mirb.) Franco, under the bark, D. Doychev leg. [UF]; Lyulin Mts, $700 \mathrm{~m} \mathrm{~N}$ of "Sts Cyril and Methodius" Monastery, 42³9'20.9”'N, 2311'10.3”E, $930 \mathrm{~m}$ a.s.1., 23.xi.2017, 2 ex., dead standing trunk of Sorbus domestica L. with galleries of Scolytus mali (Bechstein, 1805), under the bark, D. Doychev leg. [UF]; Western Rhodopes Mts, SW of Peshtera, near Novomahlenska Reka Riv., 4200'31.1'N, 24¹6’47.3”'E, 570 m a.s.l., hornbeam forest, 30.vi.2020 - 26.vii.2020, $1 \hat{\jmath}, 1$ o, flight interception trap, O. Sivilov \& H. Hristova leg. [BFUS] (Fig. 2A); Stara Planina Mts, Central Balkan Range, SW of Chiflik Vill. (Troyan Municipality), near Beli Osam Riv., 4249'24.4'N, $24^{\circ} 32^{\prime} 27.0^{\prime \prime} \mathrm{E}, 760 \mathrm{~m}$ a.s.l., beech forest (Fagus sylvatica L.) with solitary trees of Populus tremula L., Abies alba Mill. and other tree species, 4.vii.2020 -
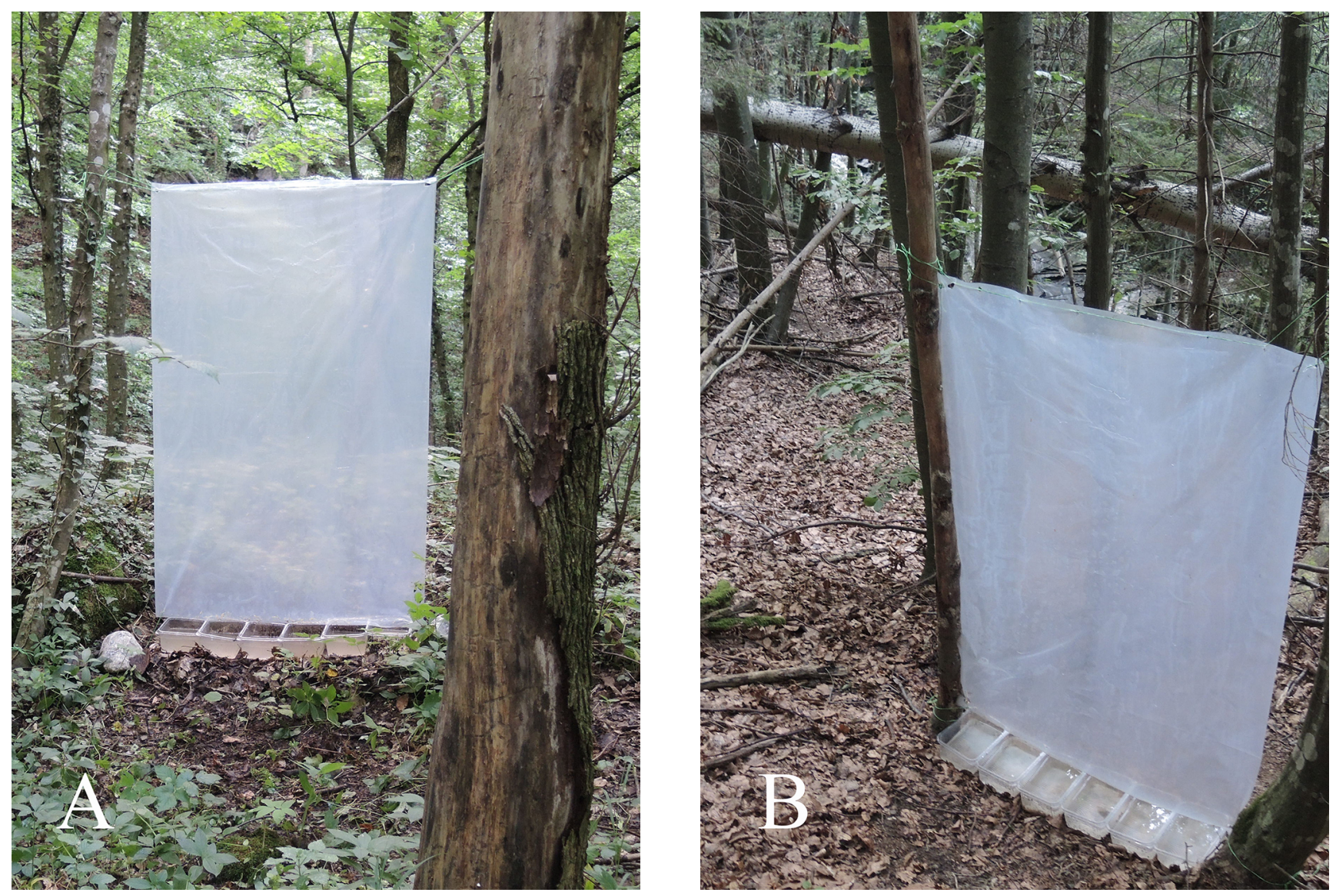

Fig. 2. Habitats of Pediacus dermestoides in Bulgaria: (A) Western Rhodopes Mts, Peshtera locality, (B) Stara Planina Mts, Chiflik locality. 


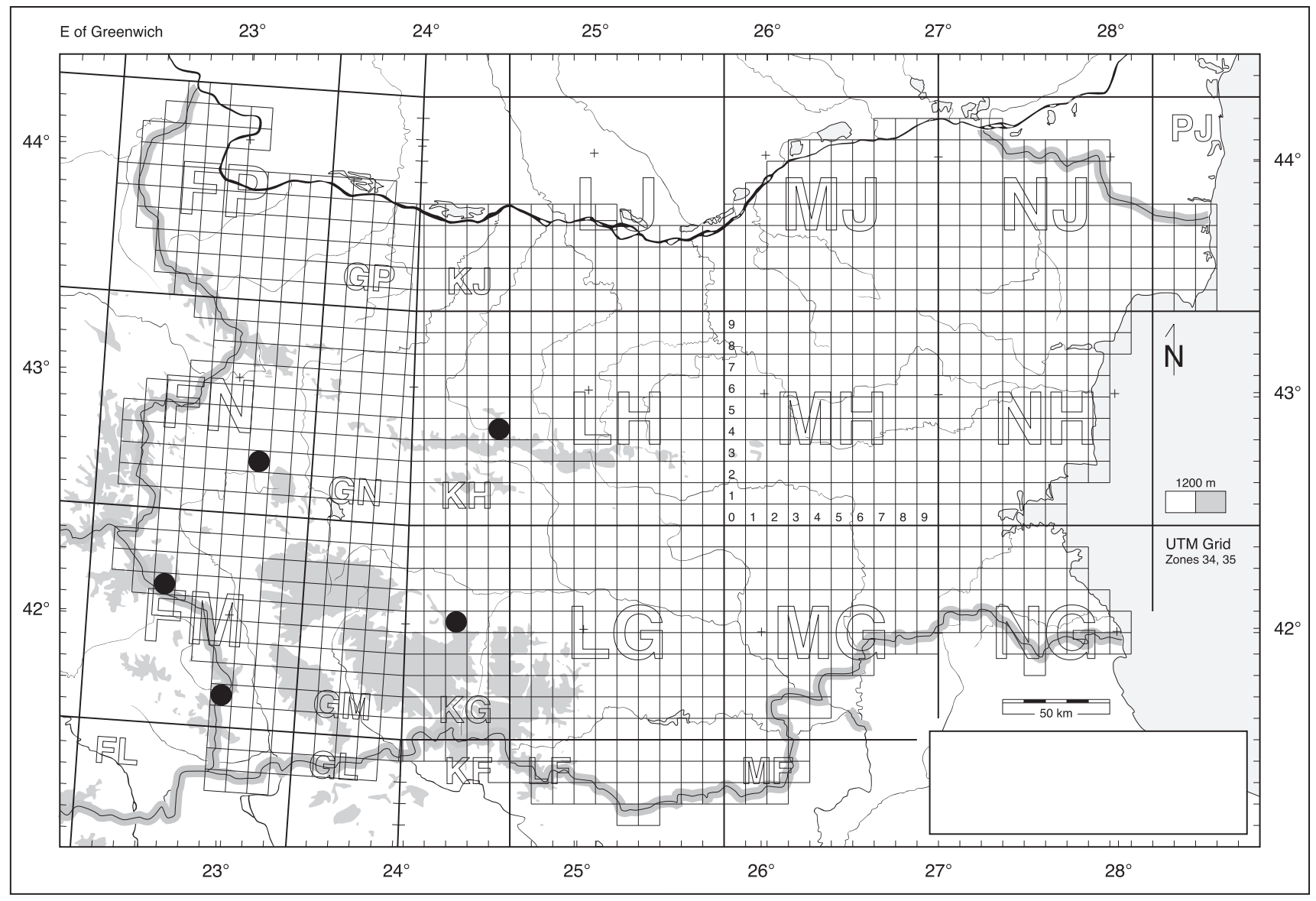

Fig. 3. Localities of Pediacus dermestoides in Bulgaria.

30.vii.2020, 1 $\widehat{\partial}$, flight interception trap, O. Sivilov \& H. Hristova leg. [BFUS] (Fig. 2B).

All the specimens examined were collected as adults. The species can be recognised by the shape of the pronotum, shape of the antennomeres and the morphology of the aedeagus (Thomas, 2003). The adults of Pediacus can be distinguished from those of Cucujus by a number of characters, listed by Guéorguiev et al. (2008).

In Mainland Europe, the genus Pediacus is represented by the species $P$. depressus (Herbst, 1797), $P$. dermestoides (Fabricius, 1792) and P. fuscus Erichson, 1845 (Wegrzynowicz, 2007; Marris \& Ślipiński, 2014). The diagnostic morphological characters of the three species are summarised and illustrated by Thomas (2003). All three species have a relatively wide distributional range (Wegrzynowicz, 2007) but only P. dermestoides (Fabricius, 1792) has been recently reported from SE Europe (a single finding from North Macedonia) (Guéorguiev et al., 2010). The present record of the species is the first one for Bulgaria and the second for the Balkan Peninsula.

Biology of the genus Pediacus is insufficiently studied (Marris \& Ślipiński, 2014). Species of the genus are found under the bark of dead coniferous and deciduous trees (Thomas, 2003; Marris \& Ślipiński, 2014). The species $P$. dermestoides is classified as "Data Deficient" in the European Red List of Saproxylic Beetles (Nieto \& Alexander, 2010; Cálix et al., 2018). In North Macedonia, the species was collected under the bark of Platanus orientalis L. (Guéorguiev et al., 2010). In the present paper, we report the association of $P$. dermestoides with the tree species Pinus sylvestris, Pseudotsuga menziesii and Sorbus domestica. A number of studies have shown that the flight interception traps are effective for monitoring of $C$. cinnaberinus populations (e.g. Schlaghamerský et al., 2008; Vrezec et al., 2012). We demonstrate that they are also suitable for collecting representatives of the genus Pediacus as well. 
In two of the reported in the present study five localities, Peshtera and Chiflik Vill. (Fig. 2A, B) another species of the family, C. cinnaberinus, was found in previous studies (Bekchiev et al., 2018). Probably $P$. dermestoides is a widespread in the mountain forest habitats with dead wood retention in the country. Its populations appear to exist in low numbers in Bulgaria and it has been overlooked in previous studies. The distributional map, based on reported localities of the species in Bulgaria, is presented in Fig. 3.

\section{Acknowledgements}

The authors wish to thank Stanislav Abadjiev (National Museum of Natural History, Sofia, Bulgaria) for the permission to use the map template in Fig. 3.

\section{References}

Bekchiev R., Guéorguiev B., Kostova R., Chehlarov E., Sivilov O. 2018 New records of rare and threatened beetles (Insecta: Coleoptera) in Bulgaria. Acta Zoologica Bulgarica 70 (4): 501-506.

Cálix M., Alexander K.N.A., Nieto A., Dodelin B., Soldati F., Telnov D., Vazquez-Albalate X., Aleksandrowicz O., Audisio P., Istrate P., Jansson N., Legakis A., Liberto A., Makris C., Merkl O., Mugerwa Pettersson R., Schlaghamersky J., Bologna M.A., Brustel H., Buse J., Novák V., Purchart L. 2018 European Red List of Saproxylic Beetles. Brussels, Belgium: IUCN, https:// portals.iucn.org/library/node/47296

Gjorgjievska A.C., Mattila J., Ahlroth P., Hristovski S. 2020 First records of rare saproxylic beetle Cucujus cinnaberinus (Scopoli, 1763) in the Republic of North Macedonia and Montenegro. Acta Musei Macedonici Scientiarum Naturalium 23 (1): 45-50.

Guéorguiev B., Doychev D., Ovcharov D. 2008 Cucujidae (Coleoptera: Cucujoidea) - a new family to the fauna of Bulgaria. Historia naturalis bulgarica 19: 93-97. https://doi.org/10.5281/zenodo. 4043684

Guéorguiev B., Bekchiev R., Chehlarov E., Hristovski S., Preliḱ D., Cvetkovska-Gorgievska A. 2010 New Coleoptera (Insecta) species from Republic of Macedonia. Acta Zoologica Bulgarica 62 (3): 363-365.
Kulijer D., Miljević I. 2017 Novi podaci i distribucija saproksilnih vrsta tvrdokrilaca (Coleoptera) od značaja za uspostavu ekološke mreže Natura 2000, na teritoriji Nacionalnog parka Sutjeska i širem području planine Zelengore. Glasnik Šumarskog fakulteta Univerziteta u Banjoj Luci 26: 5-14. https://doi.org/10.7251/GSF1726005K

Marris J.W.M., Ślipiński A. 2014 A revision of the Pediacus Shuckard 1839 (Coleoptera: Cucujidae) of Asia and Australasia. Zootaxa 3754 (1): 32-58. https://doi.org/10.11646/zootaxa.3754.1.2

Nieto A., Alexander K.N.A. 2010 European Red List of Saproxylic Beetles. Publications Office of the European Union, Luxembourg, viii +45 pp. https: //doi.org/10.2779/84561

Schlaghamerský J, Maňák V, Čechovský P. 2008 On the mass occurrence of two rare saproxylic beetles, Cucujus cinnaberinus (Cucujidae) and Dircaea australis (Melandryidae), in South Moravian floodplain forests. Revue d'Écologie (la Terre et la Vie) 63 (suppt. 10): 115-121.

Thomas M.C. 2003 A revision of Pediacus Shuckard (Coleoptera: Cucujidae) for America north of Mexico, with notes on other species. Insecta Mundi 17 (3-4): 157-177.

Vrezec A., Ambrožič Š., Kapla, A. 2012 An overview of sampling methods tests for monitoring schemes of saproxylic beetles in the scope of Natura 2000 in Slovenia. In: Jurc M. (ed.) Saproxylic beetles in Europe: monitoring, biology and conservation. Studia Forestalia Slovenica / Professional and Scientific Works 137, Ljubljana, 73-90.

Wegrzynowicz P. 2007 Family Cucujidae Latreille, 1802. In: Löbl I., Smetana A. (eds) Catalogue of Palaearctic Coleoptera. Volume 4. Elateroidea Derontoidea - Bostrichoidea - Lymexyloidea Cleroidea - Cucujoidea. Apollo Books, Stenstrup, 502-503. 